\title{
Does the target market affect bank performance? Evidence from the geographic diversification of city commercial banks in China
}

Xiaonan Li ${ }^{*}$ and anang Song

* Correspondence:

lixiaonan19901008@163.com

Department of Finance, Business

School, Renmin University of China,

Beijing 100872, China

\begin{abstract}
After the opening up of the banking sector to domestic and foreign capitals which is approved by the Chinese government, the China Banking Regulatory Commission (CBRC) has permitted city commercial banks to diversify geographically. Since this deregulation in 2006, city commercial banks began to geographically diversify to occupy the market and acquire more financial resources. To examine the causal relationship between geographical diversification and bank performance, we construct an exogenous geographical diversification instrument using the gravityderegulation model and a policy shock. We find that bank geographical diversification negatively affects bank performance. Moreover, we conduct some mechanism tests in the Chinese context. We find that the target market with several large- and medium-sized banks and a high level of local protectionism in the target market decreases the performance of city commercial banks. Finally, cross-sectional analyses show that the impact of geographical diversification on banks' performance is more notable among city commercial banks that are younger, and have a lower capital adequacy ratio and a higher non-performing loan ratio.
\end{abstract}

Keywords: Bank deregulation, Geographical diversification, Gravity-deregulation model, Commercial banks, China
๑ The Author(s). 2021 Open Access This article is licensed under a Creative Commons Attribution 4.0 International License, which permits use, sharing, adaptation, distribution and reproduction in any medium or format, as long as you give appropriate credit to the original author(s) and the source, provide a link to the Creative Commons licence, and indicate if changes were made. The images or other third party material in this article are included in the article's Creative Commons licence, unless indicated otherwise in a credit line to the material. If material is not included in the article's Creative Commons licence and your intended use is not permitted by statutory regulation or exceeds the permitted use, you will need to obtain permission directly from the copyright holder. To view a copy of this licence, visit http://creativecommons.org/licenses/by/4.0/. 


\section{Introduction}

China has been experiencing a transition from a planned to a market economy since the 1979. Market-oriented economic reform has been proceeding gradually in each sector, but the financial sector, especially city commercial banks, ${ }^{1}$ is still highly controlled and regulated by the government. Unlike the big five state-owned commercial banks and joint-equity banks which can establish branches in the whole country, the branches of city commercial banks are confined to their "home" city. ${ }^{2}$ In February 2006 and April 2009, the China Banking Regulatory Commission (CBRC) deregulated the crossregional operations of city commercial banks. City commercial banks were permitted to establish new branches in other cities within the province where the bank is headquartered. City commercial banks began geographically expanding by establishing branches outside their "home" city.

Does geographic diversification increase or decrease banks' performance? What drives performance? Existing studies include two perspectives: One perspective considers that geographic diversification could enhance banks' performance by boosting economies of scale (Berger et al. 1999; Chandler Jr. 1977; Gertner et al. 1994), improving internal capital markets (Houston et al. 1997; Kuppuswamy and Villalonga 2016), or reducing exposure to idiosyncratic local shocks (Diamond 1984). Another perspective based on corporate governance considers that the headquarters manager will find it challenging to monitor and govern such physically dispersed branches due to their distance from the headquarters. Moreover, branch managers prefer the high-risk credit business under performance pressure.

However, this research faced two main challenges. (1) It is difficult to empirically identify the causal impact of diversification on banks' performance. (2) Other mechanisms may explain the results of this study for the Chinese market. Although existing studies find that the geographic diversification of banks leads to better banks' performance in the American market (Berger et al. 1999; Chandler Jr. 1977; Diamond 1984; Gertner et al. 1994; Houston et al. 1997; Kuppuswamy and Villalonga 2016), the results and mechanisms of diversification cause these performance effects to be lacking in the Chinese context (Cai 2016; Li 2014; Wang et al. 2012; Zhang et al. 2017). To overcome these challenges, we improve this research as follows:

First, we develop and implement the gravity model to identify the causal impact of the geographic diversification of city commercial banks' branches on their performance. The deregulation of city commercial banks is a dynamic, time-varying, and city-specific process, providing us with an opportunity to construct an exogenous geographical diversification instrument based on the gravity-deregulation model following Goetz et al. (2013). We construct the instrument in two steps: (1) We use an exogenous index: the geographic distance between the "home" city and the other cities, (2) we also consider a policy shock. This instrumental variable might be more exogenous and suitable for the Chinese background.

Second, we find some possible explanations for the results based on the Chinese context. The particularity of Chinese banking deregulation is reflected in the following

\footnotetext{
${ }^{1}$ We call them "banks" hereafter in our paper.

${ }^{2}$ In 1995, the People's Bank of China (PBC) issued a document titled "The Regulation of City Cooperative Banks," which stipulated that city commercial banks can only do business and set up branches within the scope of the city (district) in which they are located.
} 
ways. (1) The motivations for geographic expansion are different. According to the WTO rules, China needed to open up the banking market to foreign financial institutions in 2006. Accordingly, the CBRC deregulated the regional restrictions of city commercial banks. Although banks could eliminate the resource constraints of a single region and realize the optimal allocation of resources through geographic expansion (Fabrizio and Thomas 2012; Schotter et al. 2017; Wernerfelt 1995), a majority of city commercial banks were not eligible for cross-regional analysis in 2009. By the end of 2008 , the historical problems and inefficiencies of city commercial banks had been addressed, but $70 \%$ of these banks had not grown beyond the size of small-sized banks. ${ }^{3,4}$ Therefore, this deregulation policy was not suitable for all city commercial banks. Nevertheless, under deregulation, most city commercial banks have been expanding across regions. (2) Local protectionism has occurred. Since 1978, regionally decentralized authoritarian systems have allowed local governments to govern economic activities and have huge regulatory, and financial power (Poncet 2003; 2010; Xu 2011). Meanwhile, the assessment for among local officials to obtain financial resources has also caused local protectionism (Huang and Wang 2006; Wong 2003; Young 2000; Zhao and Zhang 1999). These two factors decrease the degree of integration in the domestic market (Bai et al. 2004; Poncet 2003; 2010) and increase local protectionism in China. However, as an important source of credit, $^{5}$ city commercial banks are influenced and protected by local governments. (3) The Chinese banking sector is an oligopolistic market (Liu and Huang 2002; Zhang 2006). In this market structure, smalland medium-sized banks are at a competitive disadvantage (Jiang et al. 2008). By the end of $2008,70 \%$ of city commercial banks were small-sized banks. Additionally, because banking business homogenization is critical, and the Chinese banking industry implemented interest rate liberalization from 2012, city commercial banks rarely accessed high-quality resources from new markets. In this study, we find a new perspective by using these three factors in the mechanism test.

According to our empirical strategy, the results indicate that increases in geographic diversification reduced city commercial banks' performance. This finding holds after controlling for bank fixed effects, city fixed effects, time-varying bank characteristics, and the city commercial bank-specific factors, including the loan ratio, asset ratio, capital-asset ratio, asset quality, age, and size, which also exert an influence on bank performance. This result is different from the existing research in the American market (Berger et al. 1999; Chandler Jr. 1977; Diamond 1984; Gertner et al. 1994; Houston et al. 1997; Kuppuswamy and Villalonga 2016). Therefore, we examine potential explanations for these results in the Chinese market. This perspective is different from the existing explanations of scale effects or agency problems. The mechanistic evidence suggests that the decrease in city commercial banks' performance is associated with the degree of local protectionism, the market structure of the target market, and the

\footnotetext{
${ }^{3}$ The Research Group of Graduate Faculty of the PBC (2009) ranked 177 commercial banks (includes three stated-owned policy banks, five large commercial banks, 12 joint-stock banks, 136 city commercial banks, 22 rural commercial banks and one postal savings bank) in China and lists the top 70 commercial banks. There are 38 medium-sized and small-sized city commercial banks on the list.

${ }^{4}$ According to the 2008 CBRC Annual Report, by the end of 2008, all city commercial banks with grade 6 supervision and insolvent urban credit cooperatives were cleaned up. http://zhuanti.cbrc.gov.cn/subject/ subject/nianbao2008/2.pdf (page 40, line 21)

${ }^{5}$ In 1998, the central government implemented vertical reform of state-owned banks and retrieved the credit approval authority of local branches of state-owned commercial banks.
} 
ownership of city commercial banks. Specifically, (1) the higher the proportion of largeand medium-sized banks in the target market and (2) the higher the degree of local protectionism in the target market, the lower the performance of cross-regional city commercial banks. (3) Non-state-owned city commercial banks have worse performance than their state-owned counterparts.

We contribute to this research in the following aspects. Firstly, we add a different view to the existing literature on the effects of geographical diversification on banks' performance. In the existing literature, geographic diversification is implemented by banks themselves, as in the case of bank holding companies in the US. These studies consider that geographical diversification could enlarge scale economies, relieve political risk, and increase the market control of banks. Banks have more potential resources to enhance their performance by establishing new branches (Akhigbe and Whyte 2003; Berger et al. 1999; Calomiris and Mason 2003; Chandler Jr. 1977; Diamond 1984; Gertner et al. 1994; Goetz et al. 2016; Houston et al. 1997; Hughes et al. 1996; Meslier et al. 2016). However, the deregulation in China provided a policy-driven geographic diversification of banks. We find that in an oligopolistic market, following geographic expansion, local protectionism, and the ownership of city commercial banks could worsen their performance. This result echoes recent research on financial deregulation in transitional economies.

Secondly, we explain the reasons for the geographic diversification of banks from the theory of institution-based views. Institution-based views include two fields: a formal institution and an informal institution. The existing literature discusses the causes of geographic diversification and focuses on the perspective of informal institutions. However, this study researches the influence under the formal institution. According to the institution-based view, to legitimize corporate behaviors, enterprises need to make strategic behaviors that cater to institutional requirements, possibly leading to organizational convergence or organizational efficiency obstruction (DiMaggio and Powell 1983; Meyer and Rowan 1977). This study establishes a model of the influence of geographical diversification on the market share of banks. The results show that banks induce strategic behaviors that meet the regime's requirements to legitimize branches in different places. However, such behavior eventually leads to the obstruction of enterprise efficiency.

Thirdly, although our major contribution is to propose a new perspective based on the Chinese context, we also overcome endogeneity problems. Unlike Wang et al. (2012) and Li (2014), who use the Heckman model to eliminate the sample bias, we use a policy shock and gravity model to construct an instrumental variable to overcome endogenous simultaneity. This method is relatively exogenous and suitable for Chinese banking deregulation.

The remainder of this paper is organized as follows: Section 2 introduces the banking system and banking deregulation in China. Section 3 illustrates the data and summary statistics. Section 4 demonstrates the empirical strategy of the gravity-deregulation model. Section 5 shows the empirical results. Section 6 presents the results of mechanistic research and cross-sectional analyses. Section 7 provides the conclusion.

\section{Banking deregulation in China}

Since 1956, the Chinese government has established a centrally planned economy. In the financial sector, the People's Bank of China (PBC), the only bank before 1978, was responsible for all commercial banks (including deposits, loans, and foreign exchange) and central banks. After 1978, the big four banks were successively established and 
began to take over the commercial bank business from the PBC. ${ }^{6}$ In addition to the big four state-owned commercial banks, joint-equity banks and various types of regional banks were established in the same period. In September 1983, the PBC was formally reconstructed as the central bank, conducting national macroeconomic policymaking, monetary stabilization, and financial development functions. Furthermore, the CBRC was founded in 2003 to supervise and regulate the banking industry.

In addition to the big six state-owned commercial banks and 12 joint-equity banks, 133 city commercial banks were established from 1995 to $2015 .^{7}$ These city commercial banks are established by local companies and governments. Although most city commercial banks were established using state-owned capital, their size was much smaller than that of the big five commercial banks and 12 joint-equity banks, and they were only able to concentrate on local business ${ }^{8}$ before 2006.

According to the WTO rules, China needed to open its banking market in $2006 .{ }^{9}$ The market competition in banking intensified. Accordingly, in February 2006, the CBRC issued a document titled "The Regulation of City Commercial Bank Branches," which allowed eligible banks to establish branches outside their registered cities. The conditions for branch establishment included the bank's age, total capital, registered capital, capital adequacy, non-performing loans, return on assets (ROA), and return on equity (ROE). Furthermore, the bank's regulatory rating had to be above Grade 2 (including Grade 2). ${ }^{10}$

In April 2009, the CBRC issued a document titled "Adjustment Comment on the Market Access Policy of Setting Up Branches for Small- and Medium-Sized Commercial Banks," which allowed the establishment of new branches in the province in which the bank is headquartered. The approval procedure was simplified, and the approval authority for branch applications within the province was delegated to the local banking regulator. Moreover, the minimum capital requirement for new branches was canceled. Overall, this policy was a significant deregulation of China's banking system, which reduced the cost of new branch entry applications. This banking deregulation represents a transition of the banking sector from a plan-dominated system to a market-dominated system. City commercial banks were able to open branches freely in the province where their headquarters was located.

\footnotetext{
${ }^{6}$ The big four banks include the Construction Bank of China (CCB), Agricultural Bank of China (ABC), Bank of China (BOC), and Industrial and Commercial Bank of China (ICBC). They were established during 1978 1984. Specifically, the CCB specializes in construction and infrastructure projects, the ABC concentrates on the credit business for agriculture, the $\mathrm{BOC}$ focuses on the foreign exchange business, and the ICBC focuses on the credit business for industry and commerce. In 2004, the Bank of Communications (BCM) was classified as a large state-owned bank. In 2019, the Postal Savings Bank of China (PSBC) was listed as a large state-owned commercial bank. Thus, six banks are classified as large state-owned commercial banks. ${ }^{7}$ China's commercial banking system also includes over one thousand rural commercial banks. Each is usually limited to one rural area and serves the local economy and local firms.

${ }^{8}$ Please refer to the document of PBC [1997] No. 264, http://www.pbc.gov.cn/bangongting/135485/1354 95/135499/2833451/index.html

${ }^{9}$ According to the rules of the WTO, in 2006, China needed to deregulate the geographic restrictions of RMB business for foreign financial institutions. The vast majority of these restrictions, including customers, licensing conditions for operations, and cross-regional business, were deregulated in 2006. Assessed from http://www.cbrc.gov.cn/chinese/home/docView/2858.html

${ }^{10}$ The regulatory rating refers to the "Joint-equity bank risk rating system" issued and executed by the CBRC and is not disclosed to the public. It is different from the evaluation of commercial banks themselves and the rating of social intermediary institutions. Although this is important information, we cannot obtain the results now. The website for rating standards is as follows: http://www.cbrc.gov.cn/chinese/home/docDOC_ ReadView/301.html
} 
After the deregulation, city commercial banks expanded outside their home cities. In 2006, only 19 city commercial banks set up new branches outside their home cities. However, in 2016, 111 did so, accounting for $83 \%$ of the city commercial bank sector. In 2006, the total number of branches of city commercial banks was 5645, while in 2016, the total was 15,891. The number of branches in other cities was 35 in 2006, and this value increased to 4427 in 2016. Detailed information is shown in Figs. 1 and 2.

Banking deregulation drove the growth of the city commercial banks' size and promoted banking competition. From 2006 to 2016, the proportion of the assets of the city commercial banks to the total scale of the banking industry increased from $6.4 \%$ to $12.2 \%$. Thus, the market share of city commercial banks increased. However, after the deregulation, the non-performing loan (NPL) balance of city commercial banks increased from 65.47 billion yuan to 149.8 billion yuan. The proportion of the non-NPL balance in the banking industry increased from $5.2 \%$ to $10 \%$ during the same period. Detailed information is shown in Fig. 3.

\section{Sample selection and summary statistics \\ Data}

The data in this research are of three types: information on city commercial bank branches, bank-level financial information, and regional macro data. We collect information on city commercial banks from the CBRC official website. The sample period is from 2006 to 2016 and the sample includes the full name, ID, location, date of approval, and opening date for each subordinate bank. Bank-level financial information is acquired from three sources, including the Chinese Research Data Services Platform (CNRDS), the Bankscope database, and city commercial banks' annual reports. The CNRDS and Bankscope database include a majority of the accounting information of city commercial banks. We supplemented and verified the information on the city commercial banks with annual bank reports. The regional macro data were acquired from the China Stock Market and Accounting Research Database (CSMAR), the CEIC, and the local statistical bureaus. Finally, our sample includes 91 banks and 933 bank-year

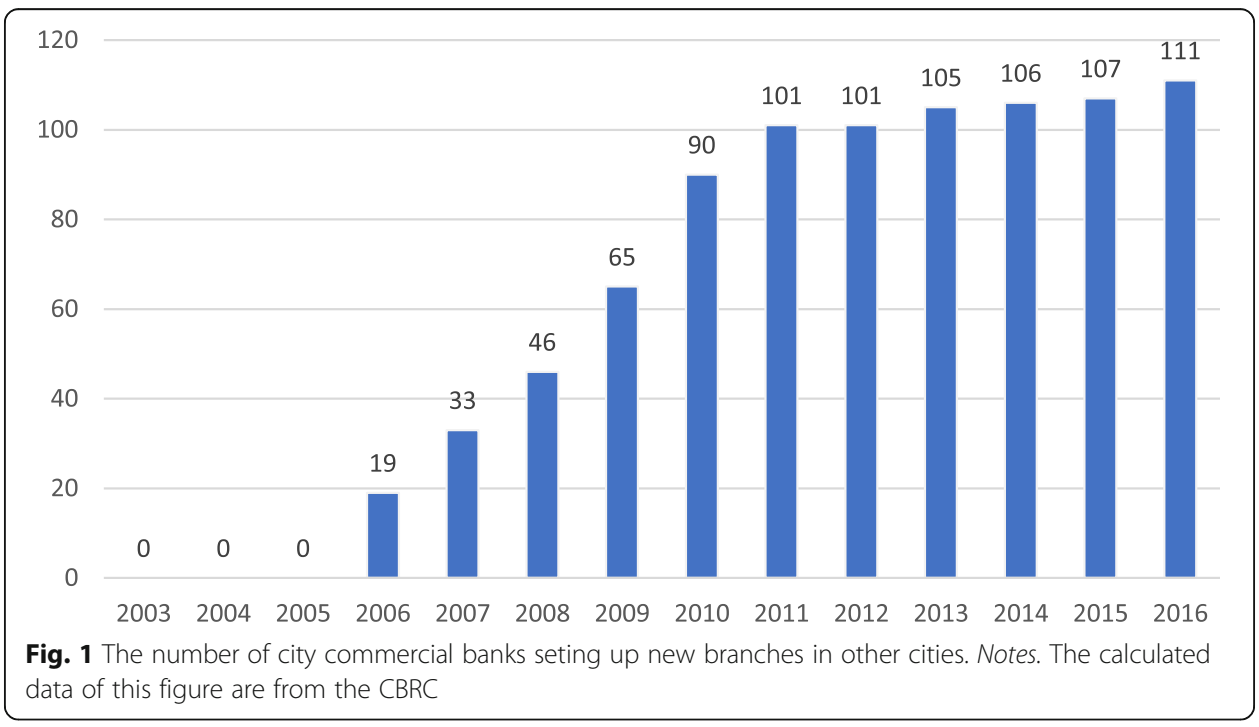




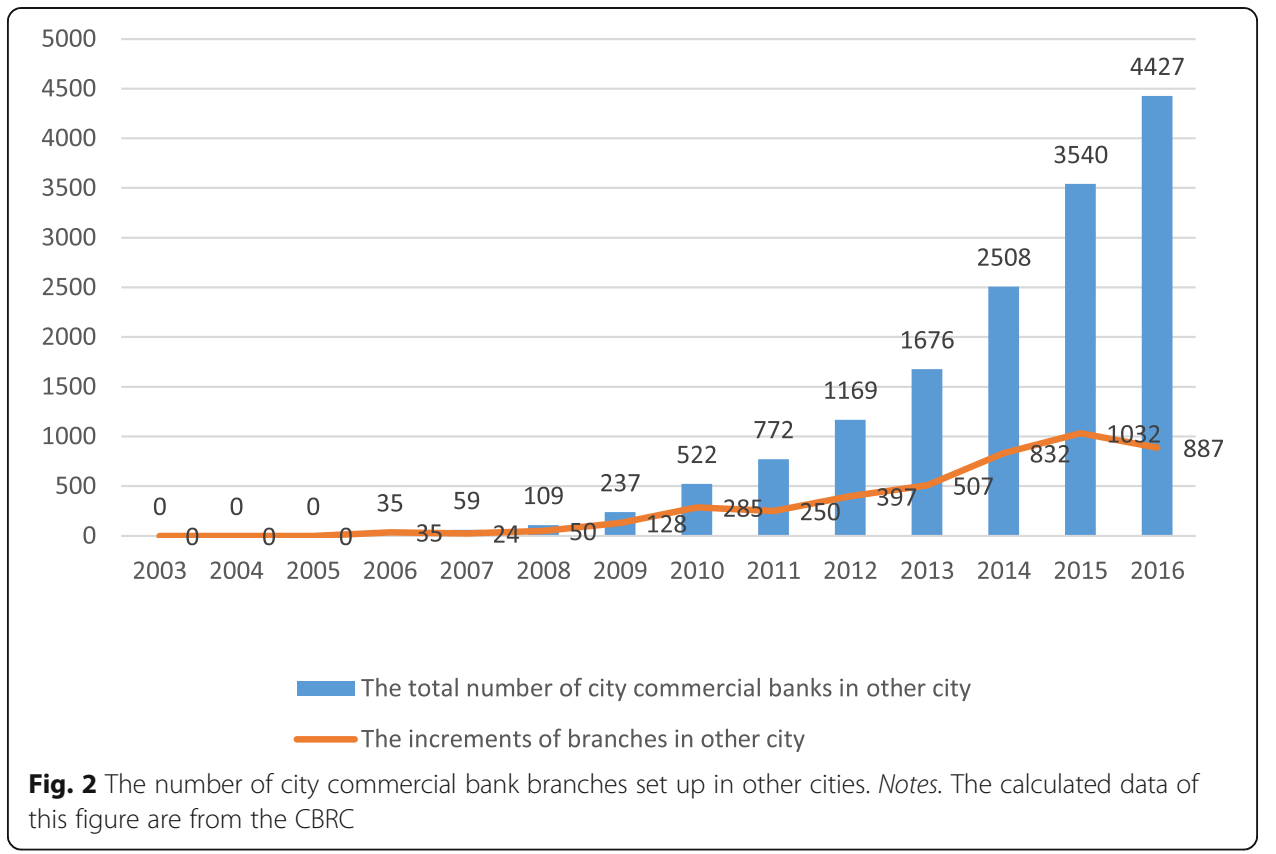

observations from 2006 to 2016. All variables are winsorized at the 1\% and 99\% levels to eliminate outliers.

\section{Sample selection}

We collated the restrictions on bank deregulation in Chinese banking to ensure that our samples were clean. In China, different banks are subject to different regulations when setting up new branches. There are almost no geographic restrictions for the big six state-owned banks. Joint-equity banks are restricted only quantitatively when the

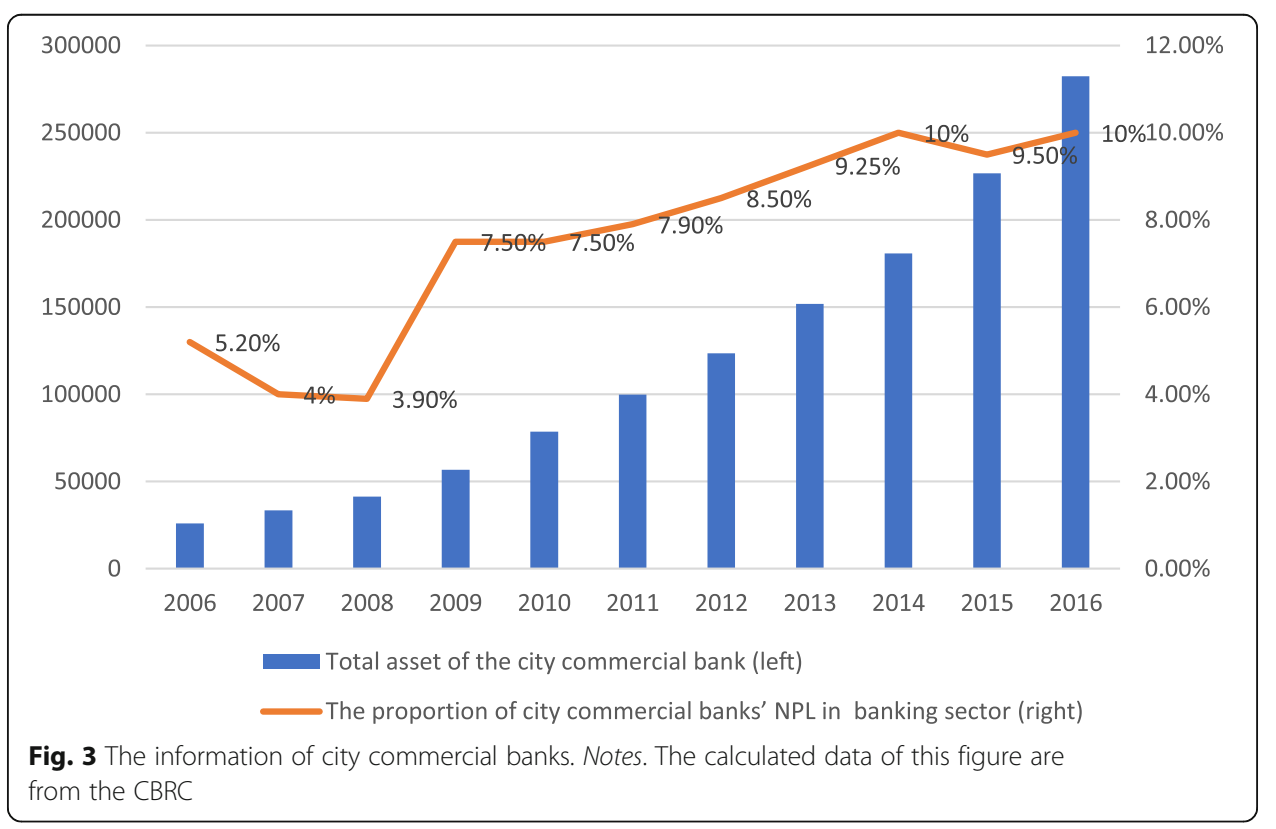


bank branches are cross-regional. There are two types of commercial banks with geographical operational restrictions: city commercial banks and rural commercial banks. Rural commercial banks continue to be regulated. Based on the deregulation of the geographic restrictions on city commercial banks since 2006, only eligible city commercial banks can be cross-regional and apply for the CBRC's approval. After April 2009, geographic restrictions were further deregulated, and the number of city commercial banks increased dramatically. Therefore, city commercial banks are different from other types of banks. However, in some studies, authors choose samples that include all types of banks in China. This study uses a sample of city commercial banks to study their geographical diversification to avoid these challenges. Specifically, our sample does not include banks subject to mergers and acquisitions (such as Huishang Bank) or reorganizations because there is no exact information on their expansion before these changes.

\section{Variable}

To measure geographical diversification of a city commercial bank, we use the branch dispersion index $(1-H H I)$, similar to a Herfindahl-Hirschman index, described as 1 minus the sum of the squared ratios of the branches of subsidiaries in each city to the sum of the total branches in all the cities where a city commercial bank operates. This index ranges from 0 to 1 . This index includes larger values for higher degrees of geographical diversification. We also use two proxy variables for geographical diversification in the preliminary results: a diversification dummy and the average distance between the home city and the target market as an alternative measure of $1-H H I$.

Following Li (2014) and Cai (2016), we use city commercial banks' financial data. We construct four proxies to measure bank performance: ROA, ROE, NPL ratio, and operating cost. Furthermore, a proxy measures the market share, given as a city commercial bank's total proportion of the total loans of all city commercial banks each year. We also use some bank-level accounting variables as controllers or alternative measures in the following empirics: loan ratio, asset ratio, capital ratio, asset quality, GDP of bank headquarters, bank age, and bank size. The definitions of the variables are presented in the Appendix.

\section{Sample descriptive statistics}

Table 1 presents the sample descriptive statistics. We distribute the full sample into two subsamples: diversified and non-diversified banks. Although the deregulation of city commercial banks is in force simultaneously, the banks' geographic expansion occurs at different times. In our sample, one bank could be classified as a non-diversified bank in the year before the expansion and a diversified bank in the year following its diversification out of the city of the headquarter. On average, diversified banks have 21.65 branches in 3.26 other cities. Moreover, in comparison, diversified banks are larger-sized and older and have more NPLs, non-interest income, and fixed assets than non-diversified banks. However, these observations have lower NPL ratios, lower capital adequacy ratios, and lower ROE. Most of these differences are statistically significant at the $1 \%$ level. 
Table 1 Summary statistics for diversified and non-diversified banks

\begin{tabular}{|c|c|c|c|c|c|c|c|c|c|c|}
\hline \multirow[t]{2}{*}{ Variable } & \multicolumn{4}{|c|}{ Diversified banks } & \multicolumn{4}{|c|}{ Non-diversified banks } & \multirow{2}{*}{$\begin{array}{l}\text { Difference } \\
\text { in mean } \\
t \text {-stat }\end{array}$} & \multirow{2}{*}{$\begin{array}{l}\text { Difference in } \\
\text { median } \\
\text { Wilcoxon } \\
z \text {-value }\end{array}$} \\
\hline & $\mathrm{N}$ & Mean & Std. & Median & $\mathrm{N}$ & Mean & Std. & Median & & \\
\hline$R O A$ & 650 & 0.010 & 0.010 & 0.010 & 256 & 0.010 & 0.030 & 0.010 & 0.010 & 1.764 \\
\hline$R O E$ & 651 & 0.160 & 0.090 & 0.150 & 257 & 0.260 & 1.200 & 0.140 & $0.107^{b}$ & 1.221 \\
\hline NPL ratio & 654 & 1.220 & 1 & 1.030 & 261 & 2.310 & 2.640 & 1.670 & $1.086^{c}$ & $38.990^{c}$ \\
\hline Cost & 649 & 0.020 & 0.010 & 0.020 & 229 & 0.020 & 0.010 & 0.020 & $0.004^{c}$ & $31.482^{c}$ \\
\hline $1-H H I$ & 655 & 0.350 & 0.230 & 0.320 & 276 & 0 & 0 & 0 & $-0.348^{c}$ & $391.457^{c}$ \\
\hline Equity & 655 & 8.490 & 0.900 & 8.510 & 265 & 7.080 & 0.890 & 7.110 & $-1.401^{\mathrm{c}}$ & $245.006^{c}$ \\
\hline Capital & 639 & 13.620 & 3.570 & 12.990 & 255 & 71.660 & 942.50 & 11.570 & 58.040 & $39.640^{c}$ \\
\hline$N P L$ & 654 & 7.930 & 1.470 & 8.150 & 262 & 6.960 & 2.010 & 7.220 & $-0.968^{c}$ & $45.247^{c}$ \\
\hline Loan ratio & 652 & 0.450 & 0.170 & 0.440 & 259 & 0.500 & 0.130 & 0.530 & $0.053^{c}$ & $43.005^{c}$ \\
\hline Asset quality & 644 & 0.040 & 0.190 & 0.0300 & 252 & 0.050 & 0.220 & 0.030 & 0.010 & $3.732^{\mathrm{a}}$ \\
\hline NII & 647 & 2.540 & 1.250 & 2.560 & 224 & 1.48 & 1.09 & 1.32 & $-1.053^{c}$ & $101.166^{c}$ \\
\hline Fixed asset & 646 & 6.211 & 1.150 & 6.260 & 224 & 4.580 & 1.670 & 5.00 & $-1.626^{c}$ & $142.587^{c}$ \\
\hline Size & 654 & 10.730 & 12.090 & 6.840 & 265 & 7.130 & 55.35 & 1.850 & -3.607 & $205.188^{c}$ \\
\hline Age & 657 & 12.230 & 4.690 & 13 & 276 & 8.390 & 4.370 & 9 & $-3.842^{c}$ & $127.966^{c}$ \\
\hline No. of branches & 657 & 76.450 & 52.420 & 65 & 276 & 40.68 & 25.460 & 35 & $-35.762^{c}$ & $97.391^{c}$ \\
\hline No. of cities & 657 & 3.260 & 2.840 & 3 & 276 & 0.01 & 0.12 & 0 & $-3.241^{c}$ & $327.907^{c}$ \\
\hline $\begin{array}{l}\text { No. of branches in } \\
\text { other cities }\end{array}$ & 657 & 21.650 & 30.220 & 10 & 276 & 0.360 & 3.130 & 0 & $-21.291^{c}$ & $359.093^{c}$ \\
\hline
\end{tabular}

Notes. The full sample range from 2006 to 2016. A bank is defined as diversified if it has subsidiaries in more than one city. The sample is divided according to the bank-year observations; a bank can be diversified in one year and nondiversified in another year. Thus, appearing in both groups. All variables defined in the Appendix. ${ }^{a}{ }^{b}$, and ${ }^{c}$ denote statistical significance at $10 \%, 5 \%$ and $1 \%$ levels, respectively. The original amount of equity, NPL, fixed asset, and noninterest income is reported instead of log form (in units of million yuan)

\section{Identification strategy}

An empirical challenge in this research is that geographical diversification may be endogenous, meaning there may be unobservable variables that affect both bank geographical diversification and performance. To address these challenges, we employ the gravity-deregulation model to construct a time-varying and bank-specific exogenous instrument, following Goetz et al. (2013). According to the gravity-deregulation model, we select an exogenous variable: distance. Distance is the straight-line distance between the city center where the new branch is located and the city center where the city commercial bank's headquarter is located. Moreover, this variable is relevant to $1-H H I$; however, it is not directly relevant to bank performance. Additionally, we also consider the deregulation policy shock in the model. Due to the difference between the policies in 2006 and 2009, there are two ways to show the role of deregulation in constructing an instrument. In 2006, the CBRC allowed only qualified city commercial banks to establish cross-regional branches; however, this standard was not disclosed to the public. This evaluation system includes two parts: qualitative and quantitative. From 2006 to 2009, for observations in which city commercial banks did not meet the quantitative standard, we set the projected share equal to 0 . In 2009, the regulation preventing city commercial banks from setting up branches in other cities was completely lifted.

We collect the cross-regional information for each city commercial bank from the CBRC website, which publicizes all license information on bank branches to construct 
the instrument. Then, we calculate the probability of a city commercial bank entering the target market to establish subsidiaries based on the gravity-deregulation model following Goetz et al. (2013). The model specification is as follows:

$$
\text { bankbranch }_{b, i, c, t}=\alpha+\beta \times \text { Distance }_{b, i, c}++\delta_{i}+\tau_{t}+\varepsilon_{i, t},
$$

where, bank branch $_{b, i, c, t}$ is the number of branches that bank $b$ in city $c$, headquartered in city $i$, establishes in year $t$; Distance $_{b, i, c}$ is the distance between bank $b$ 's "home" city and the other city $c$. We also add the home city and year fixed effects and cluster standard errors at a city-year level. Accordingly, we expect the coefficient on distance and relative market size to be negative, meaning that banks are more attracted to establish branches in neighboring cities and relatively larger markets. We employ a Logit model to estimate model (1). The results are presented in Table 2. Column (1) reports that the gravity model could explain city commercial banks' expansion. The results show a negative and significant relationship between banks' expansion and distance. The results indicate that banks prefer to establish branches in cities close to their headquarters, consistent with Goetz et al. (2013).

We use the estimates in Table 2 to construct the instrumental variable (1-Predicted $H H I)$. To create the predicted value, we iterate the coefficient estimates in column (1) of Table 2 and obtain the projected value of city commercial banks' branches in other cities for each year. Next, we use the projected value to compute the $1-H H I$ of bank branches as the instrument for actual geographical diversification in the first-stage regression. This index ranges from 0 to 1 , with larger values indicating a greater extent of geographical diversification and 0 values indicating that the city commercial bank has no geographic expansion. We construct the instrumental variables by the predicted value.

\section{Empirical results}

This section includes three sub-sections: (1) preliminary results; (2) additional control variable results; and (3) two-stage least squares regression (2SLS) using the instrument.

\section{Preliminary results}

In this part, we estimate the relationship between geographical diversification and city commercial banks' performance using ordinary least squares (OLS) regressions. The model specification is as follows:

$$
Y_{i, t}=\alpha+\gamma \times \operatorname{Proxy}+\delta_{i}+\tau_{t}+\varepsilon_{i, t}
$$

Table 2 Gravity-deregulation model

\begin{tabular}{ll}
\hline Dependent variable & Branch \\
\hline Distance & $-0.002^{\complement}(0.000)$ \\
Constant & $1.835^{\complement}(0.161)$ \\
Year fixed effects & Yes \\
Home city fixed effect & Yes \\
$N$ & 9754 \\
$R^{2}$ & 0.315 \\
\hline
\end{tabular}

Notes. This table reports the average marginal effects of Logit regressions. Standard errors are robust and reported in parentheses. ${ }^{a^{* * *}}, b^{* *}$, and ${ }^{c^{*}}$ indicate significance at $1 \%, 5 \%$, and $10 \%$ levels, respectively 
where $Y_{i, t}$ denotes the performance of city commercial bank $i$ in year $t$, and bank performance includes four variables: ROA, ROE, NPL ratio, and cost. Additionally, we include a variable for market share. Proxy denotes alternative measures of city commercial banks' geographical diversification, including $1-H H I$, average distance, and a diversification dummy. ${ }^{11} \delta_{i}$ is bank fixed effects; $\tau_{t}$ is year fixed effects; and $\varepsilon_{i, t}$ is the residual. In the preliminary tests, we control only for the year and city commercial bank fixed effects.

The preliminary results are shown in Table 3. The relationship between geographic diversification and bank performance is negative. Meanwhile, geographic diversification has a positive and significant relationship with market share. The resulting coefficient indicates that if a median-sized non-diversified city commercial bank begins to expand, its performance will decrease with depressed ROE, and increased NPL ratio, and increased costs. The results indicate that a bank's geographic expansion increases its market share but does not improve performance.

\section{Test of additional control variables}

In this part, we estimate the causal effects between bank geographic diversification and bank performance by controlling for city commercial bank-level and city-level factors. We use the $H H I$ of city commercial banks' branches. The model specification is as follows:

$$
Y_{i, t}=\alpha+\gamma_{1} \times(1-H H I)+\gamma_{2} X_{i, t}+\delta_{i}+\tau_{t}+\varepsilon_{i, t},
$$

where $Y_{i, t}$ denotes the performance of city commercial bank $i$ in year $t$ and includes four variables: ROA, ROE, NPL ratio, cost, and market share; $(1-H H I)$ denotes bank geographical diversification. $X_{i, t}$ is a set of bank characteristics; $\delta_{i}$ is banks' fixed effects; $\tau_{t}$ is year fixed effects; and $\varepsilon_{i, t}$ is the residual. In this specification, $\gamma_{1}$ indicates whether the banks' geographical diversification influences their performance.

The test results for additional control variables are shown in Table 4. In this test, we control for city commercial bank-specific factors, including the loan ratio, asset ratio, capital, asset quality, and banks' age and size. The city-level specific variable uses the GDP of the bank's "home" city. The results show that city commercial banks' geographic diversification has a negative relationship with performance but a positive and significant relationship to market share. Specifically, the ROA and ROE of the bank decline, and the NPL ratio, cost, and market share increase. All the results are significant at $5 \%$. This result is consistent with the preliminary results.

\section{Two-stage least squares regression (2SLS)}

This section highlights $(1$ - Predicted $H H I)$ as an exogenous instrument to estimate model (2). The first-stage model is as follows:

$$
(1-H H I)_{i, t}=\alpha+\beta \times(1-\text { PredictedHHI })+\delta_{i}+\tau_{t}+\varepsilon_{i, t} .
$$

\footnotetext{
${ }^{11}$ These three measures of geographical diversification of city commercial banks are as follows: (i) 1 minus the $H H I$ of the distribution of the bank's branches across cities; (ii) the average distance between a city commercial bank's "home" city and the city of its subsidiary; and (iii) a dummy variable that takes a value of 1 if the city commercial bank set up branches outside its "home" city, and 0 otherwise.
} 
Table 3 Geographic diversification and bank performance: baseline result

\begin{tabular}{|c|c|c|c|c|c|}
\hline Dependent variable & (1) $R O A$ & (2) $R O E$ & (3) NPL ratio & (4) Cost & (5) Market share \\
\hline \multicolumn{6}{|l|}{ Panel A: 1-HHI } \\
\hline $1-H H I$ & $-0.004^{c}(0.001)$ & $-0.064^{\mathrm{a}}(0.037)$ & $1.913^{\mathrm{b}}(0.796)$ & $0.005^{\mathrm{a}}(0.003)$ & $0.528^{\mathrm{C}}(0.124)$ \\
\hline Constant & $0.005(0.003)$ & $0.099^{c}(0.010)$ & $8.077^{c}(1.200)$ & $0.021^{c}(0.007)$ & $0.884^{\mathrm{C}}(0.482)$ \\
\hline$N$ & 933 & 933 & 933 & 933 & 933 \\
\hline$R^{2}$ & 0.421 & 0.399 & 0.381 & 0.301 & 0.914 \\
\hline \multicolumn{6}{|l|}{ Panel B: Avg distance } \\
\hline Avg distance & $-0.001^{b}(0.002)$ & $-0.005^{b}(0.002)$ & $0.011(0.088)$ & $0.001^{\mathrm{b}}(0.003)$ & $0.022^{b}(0.011)$ \\
\hline Constant & $0.004^{\complement}(0.001)$ & $0.101^{b}(0.046)$ & $7.847^{\mathrm{C}}(1.318)$ & $0.020^{\complement}(0.007)$ & $-0.921^{a}(0.515)$ \\
\hline N & 933 & 933 & 933 & 933 & 933 \\
\hline$R^{2}$ & 0.424 & 0.396 & 0.369 & 0.302 & 0.914 \\
\hline \multicolumn{6}{|c|}{ Panel C: Diversification dummy } \\
\hline Diversification dummy & $-0.001(0.001)$ & $-0.019^{b}(0.008)$ & $0.675^{b}(0.293)$ & $0.003^{b}(0.001)$ & $0.055^{\mathrm{C}}(0.040)$ \\
\hline Constant & $0.005^{\complement}(0.001)$ & $0.104^{b}(0.046)$ & $7.682^{c}(1.311)$ & $0.020^{\complement}(0.006)$ & $0.964^{c}(0.141)$ \\
\hline N & 933 & 933 & 933 & 933 & 933 \\
\hline$R^{2}$ & 0.415 & 0.396 & 0.380 & 0.306 & 0.908 \\
\hline Year fixed effects & Yes & Yes & Yes & Yes & Yes \\
\hline Bank fixed effects & Yes & Yes & Yes & Yes & Yes \\
\hline
\end{tabular}

Notes. Standard errors are robust, clustered at the bank-year level, and reported in parentheses. ${ }^{\mathrm{a}},{ }^{\mathrm{b}}$, and ${ }^{\mathrm{c}}$ indicate significance at $10 \%, 5 \%$, and $1 \%$ levels, respectively

Table 4 Geographic diversification and bank performance: additional control variables test

\begin{tabular}{|c|c|c|c|c|c|}
\hline $\begin{array}{l}\text { Dependent } \\
\text { variable }\end{array}$ & (1) $R O A$ & (2) $R O E$ & (3) NPL ratio & (4) Cost & $\begin{array}{l}\text { (5) Market } \\
\text { share }\end{array}$ \\
\hline$\overline{1-H H I}$ & $\begin{array}{l}-0.005^{b} \\
(0.002)\end{array}$ & $\begin{array}{l}-0.073^{b} \\
(0.031)\end{array}$ & $2.671^{c}(0.758)$ & $0.009^{\mathrm{b}}(0.004)$ & $0.377^{\mathrm{C}}(0.082)$ \\
\hline Loan ratio & $0.015^{c}(0.002)$ & $0.038^{\mathrm{a}}(0.020)$ & $0.471(0.293)$ & $0.032^{c}(0.002)$ & $0.146^{b}(0.067)$ \\
\hline Asset ratio & $-0.014(0.009)$ & $-0.153(0.149)$ & $-6.556^{\mathrm{b}}(2.539)$ & $\begin{array}{l}-0.028^{b} \\
(0.013)\end{array}$ & $-4.494^{\mathrm{c}}(0.956)$ \\
\hline Capital & $0.007^{\mathrm{b}}(0.003)$ & $-0.300^{c}(0.072)$ & $-0.648(0.880)$ & $0.010^{\mathrm{a}}(0.006)$ & $-0.272^{\mathrm{a}}(0.141)$ \\
\hline Asset quality & $0.064^{\mathrm{b}}(0.027)$ & $-0.344(0.857)$ & $5.834(6.855)$ & $0.030(0.034)$ & $1.509^{c}(0.470)$ \\
\hline GDP & $-0.190(0.223)$ & $1.630(4.167)$ & $\begin{array}{l}-252.737^{b} \\
(105.728)\end{array}$ & $-0.281(0.417)$ & $\begin{array}{l}-63.497^{c} \\
(19.166)\end{array}$ \\
\hline Age & $0.004^{c}(0.001)$ & $0.003(0.002)$ & $-0.590^{c}(0.048)$ & $\begin{array}{l}-0.002^{c} \\
(0.002)\end{array}$ & $0.054^{c}(0.006)$ \\
\hline Size & $0.004(0.003)$ & $0.057(0.047)$ & $1.493^{\mathrm{a}}(0.884)$ & $0.014^{c}(0.005)$ & $1.201^{c}(0.340)$ \\
\hline Constant & $-0.003^{\mathrm{a}}(0.002)$ & $0.091^{C}(0.028)$ & $9.881^{C}(0.367)$ & $0.025^{c}(0.002)$ & $-0.411^{\mathrm{c}}(0.064)$ \\
\hline N & 808 & 808 & 808 & 808 & 808 \\
\hline$R^{2}$ & 0.704 & 0.580 & 0.461 & 0.633 & 0.971 \\
\hline Year fixed effects & Yes & Yes & Yes & Yes & Yes \\
\hline Bank fixed effects & Yes & Yes & Yes & Yes & Yes \\
\hline
\end{tabular}

Notes. Standard errors are robust, clustered at the bank level, and reported in parentheses. ${ }^{\mathrm{a}}$, ${ }^{\mathrm{b}}$, and ${ }^{\mathrm{c}}$ indicate significance at the $10 \%, 5 \%$, and $1 \%$ levels, respectively 


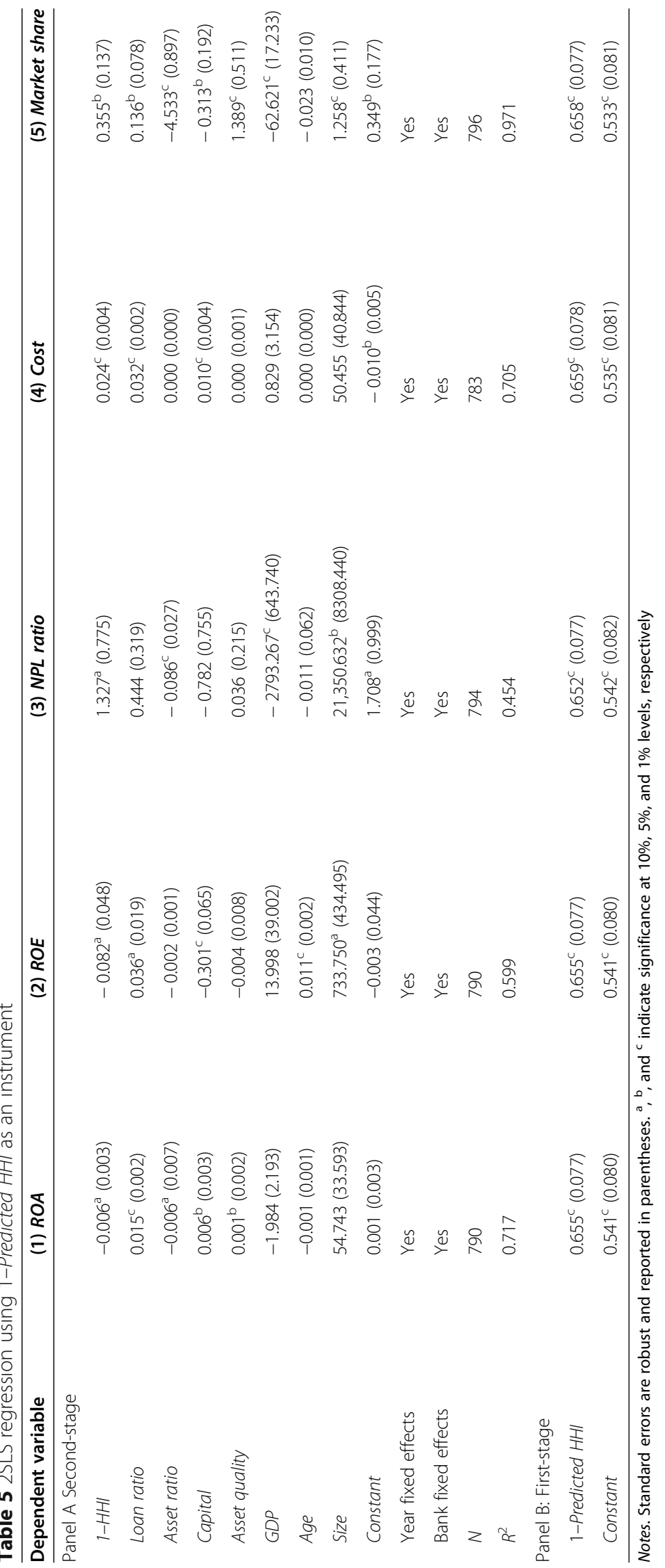


Table 5 reports the results. In the results for the first stage presented in Panel B of Table 5 , the index of $(1-$ Predicted $H H I)$ is positive and significantly associated with the actual degree of diversification at the $1 \%$ level. This means that a higher level of a bank's predicted geographical diversification is positively associated with actual bank geographical diversification at the $1 \%$ level. The result indicates that the instrument could explain diversification at the city commercial bank level. Panel A of Table 5 presents the second-stage results. The coefficient on the predicted diversification is significantly related to the bank's performance; the results consist of the baseline results. The coefficient has a positive and significant relationship with the NPL ratio, cost, and market share but a negative and significant relationship with ROA and ROE. In general, geographical diversification reduces the bank's performance.

In China, as the original intention of establishing city commercial banks is to serve the local economy, these banks can only operate in the registered city. Therefore, most city commercial banks are ill-informed about the areas outside their headquarters. After deregulation, to occupy the market, they blindly expand. Moreover, bank diversification does not result in lower risk because diversified banks may raise leverage and pursue riskier activities due to competitive pressures (Chong 1991; Demsetz and Strahan 1973). An increase in NPLs may account for this phenomenon. Banks' geographic diversification may increase organizational complexity and intensify agency problems. When a bank sets up affiliated branches far away from its "home" city, the headquarters may not be able to control these branches. Decreased ROA and ROE may account for agency problems. Existing studies consider that banks prefer investing in high-risk projects to protect their returns due to the increased distance and information asymmetry between branches and headquarters (Brickley et al. 2003; Degryse and Ongena 2005; Deng and Elyasiani 2008).

\section{Mechanisms}

Our results show a robust and negative effect of geographical diversification on bank performance. In this section, we explore the mechanisms of this research in the Chinese context. Specifically, the mechanisms include the number of large- and medium-sized banks in a target market, local protectionism, the ownership of city commercial banks, and heterogeneity characteristics between the city commercial banks.

\section{Market structure of the target market}

Although geographical diversification could expand city commercial banks' market, they also encounter competition and challenges. The banking industry in China is an oligopoly market, and state-owned banks and joint-equity commercial banks hold a major market share. In an oligopoly market, large-sized companies are likely to conspire together for higher profits (Bain 1956; Demsetz and Strahan 1973; Demirgüç-Kunt and Harry 1999). Compared with large banks, small banks prefer to offer high interest rates and over lend to enhance their competitiveness, possibly increasing risk (Franklin and Douglas 2000). Establishing a relationship with the local government could be difficult for a city commercial bank in a new market. As a new entrant, city commercial banks can acquire relatively few resources from the new market. Therefore, we predict that city 
commercial banks expanding cross-regionally to new markets with large numbers of state-owned banks and joint-equity banks would worsen performance.

To examine this hypothesis, we estimate it using Eq. (3) and divide our sample into two subsamples. ${ }^{12}$ The results are reports in Table 6. Columns (1) to (5) report the results for a subsample with a large number of state-owned banks and joint-equity banks, and columns (6) to (10) report the results for a subsample with a small number of these banks. We find that the coefficient estimates of ROA and ROE are negative in both specifications and significant at the $1 \%$ level for the former subsample but not significant for the latter subsample. The coefficient estimates for the NPL ratio and cost are positive in both specifications and significant at the $5 \%$ and $10 \%$ levels for both subsamples. However, the market share of city commercial banks in the subsample with a small number of state-owned banks and joint-equity banks is more significant than that for the subsample with several of these banks both economically and statistically. The results imply that city commercial banks that establish branches in cities with several large-sized banks have worse performance. However, although expanding to the market with a small number of large-sized banks did not increase the city commercial bank's return, it increased its market share.

\section{Ownership}

Government holding banks are a universal phenomenon worldwide (Porta 2012). According to the World Bank (2001), in the 1990s, governments held $40 \%$ of bank assets globally. There are also different views on the consequences of government intervention in finance. Compared to private banks, government banks have lower efficiency, lower revenue, poor loan quality, and a higher risk of bankruptcy (Baum et al. 2010; Cornett et al. 2008; Iannotta et al. 2007; Mian 2003; Shen and Lin 2012). However, government holding banks could remedy the market failure of private banks and address the interest of society and the public (Gerashchenko 1962; Greenwald and Stiglitz 1986; Hainz and Hakenes 2007; Lewis 1950; Stiglitz 1993; Stiglitz and Weiss 1981). These different views stem from the different levels of the political system and economic development in different countries (Körner and Schnabel 2011; Levy-Yeyati et al. 2004; Micco et al. 2007). The existing research considers that local governments acquire financial resources by intervening in city commercial banks, leading them to have high NPLs and low performance (Tian 2012). However, compared with the non-state-owned city commercial banks, the state-owned city commercial banks can access local resources from local governments (Hu and Guo 2013). They cannot achieve the optimal allocation of resources because of the oligopoly banking market in China. In this circumstance, the local government support is instrumental. We predict that non-stateowned banks show worse performance than state-owned banks.

To examine this hypothesis, we estimate it using Eq. (3) and divide our sample into two subsamples by city commercial banks' ownership. The results are seen in Table 7 . Columns (1) to (5) report the results for state-owned banks, and columns (6) to (10) report those for non-state-owned banks. We find that the coefficient estimates of ROA

\footnotetext{
${ }^{12}$ We calculate the number of state-owned banks and joint-equity banks in each target market, and then cumulate the number of state-owned banks and joint-equity banks of all the target market. Finally, divide the number of target markets. The average number of state-owned banks and joint-equity banks in target markets is the index.
} 


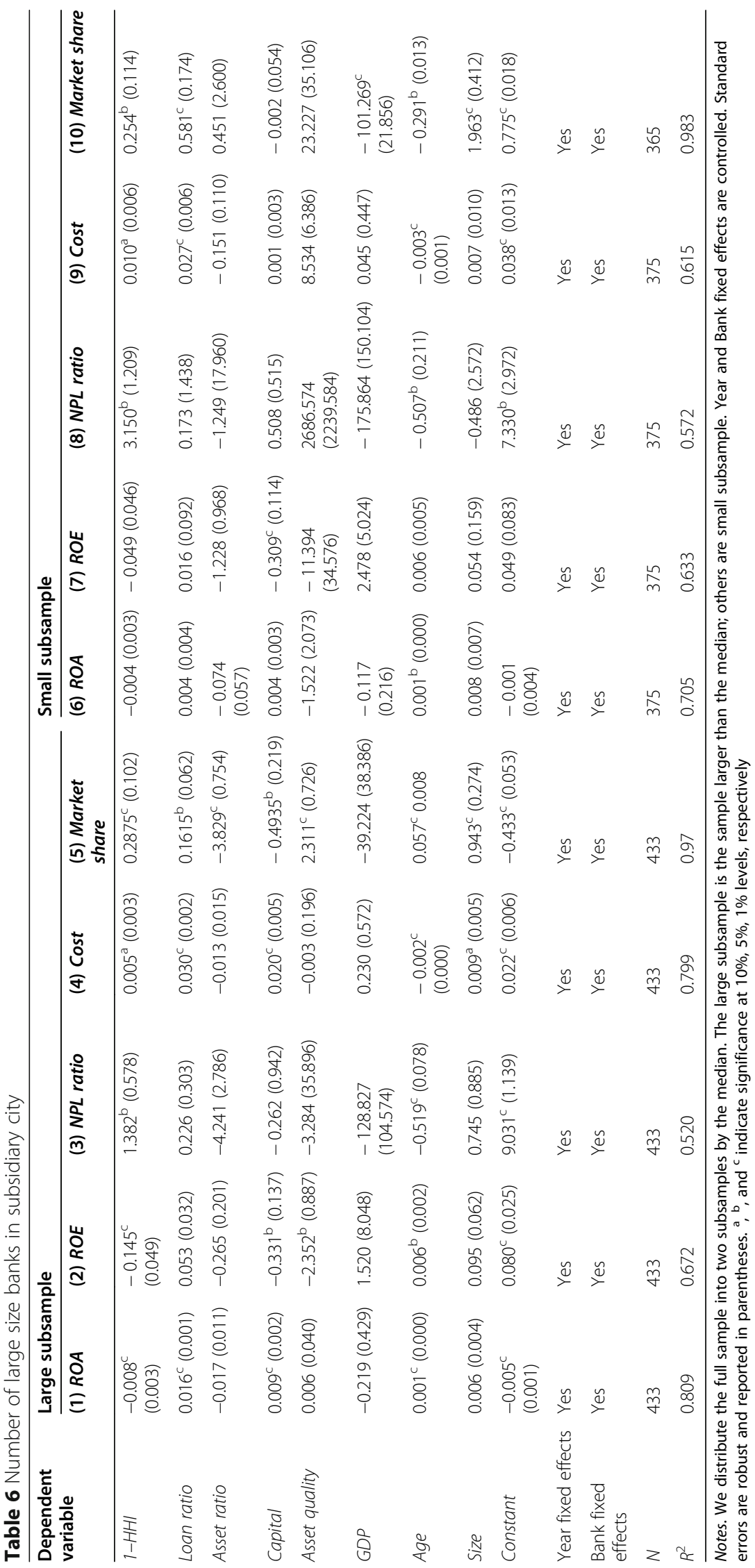




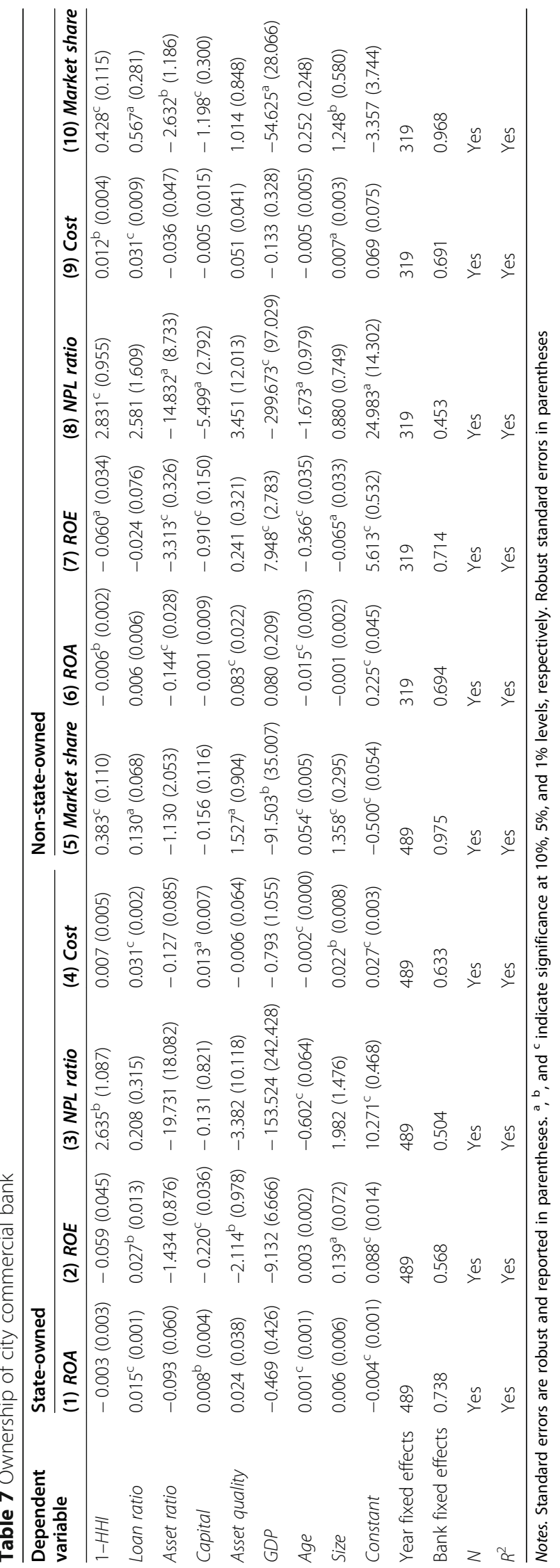


and ROE are negative in both specifications and significant for the non-state-owned sample but not significant for the state-owned sample. The coefficient estimates of the NPL ratio and market share are positive and significant for both subsamples. The cost coefficient estimates are positive and significant for the non-state-owned sample but not significant for the state-owned sample. The reason for these results may be due to the support of local governments.

\section{Local protectionism}

To protect the interests of the local economy, the local government has taken a series of actions (Bai et al. 2004; Lin and Liu 2004; Poncet, 2002). The development of city commercial banks has been deemed important by local governments as they are only financial resources that local governments can directly control (Guo 2014; Guo and Xiong 2018; Zhou 2004a; 2004b; 2007). Local governments transfer the financial resources of city commercial banks to local enterprises by controlling city commercial banks (Guo and Xiong 2018). The local city commercial banks collect the utility expenses of a city. Therefore, city commercial banks cross-regionally expanding to other cities with high levels of local protectionism would lead to poor performance. Additionally, the target market may reject the application of other city commercial banks to set up a branch, as the new branches of other city commercial banks will increase the competitiveness of the local banking industry. We hypothesize that a higher level of local protectionism in the target market will decrease the performance and market share of city commercial banks. To examine this hypothesis, we estimate the following model:

$$
\begin{aligned}
Y_{i, t}= & \alpha+\gamma(1-H H I)+\gamma_{1} \text { Protect }+\gamma_{2}(1-H H I) \times \text { Protect }+X_{i, t}+\delta_{i}+\tau_{t} \\
& +\varepsilon_{i, t}
\end{aligned}
$$

where, $Y_{i, t}$ and $(1-H H I)$ are the same as the previous model before. We add a new variable Protect and the interaction term $(1-H H I) \times$ Protect. Protect denotes the level of local protectionism in the target market. We calculate this value following $\mathrm{Hu}$ and Zhang (2005) and use the proportion of enterprise income tax as local fiscal revenue. ${ }^{13}$

The results of estimating Eq. (5) are seen in Table 8. Columns (1) and (2) present the regression for banks' ROA and ROE. The coefficient estimates of the interaction terms are negative and significant at the $1 \%$ level. In columns (3) and (4), we present the regression for banks' NPL ratio and cost: The coefficient estimates of the interaction terms are positive and significant at the $10 \%$ and $1 \%$ levels, respectively. Column (5) presents the results for market share; the coefficient of the interaction terms is negative but not significant. These results show that the higher the level of local protectionism in the target market, the worse the performance of city commercial banks. Local protectionism affects market share, consistent with local protectionism leading to market segmentation.

\section{Cross-sectional analyses}

Geographical diversification has different effects on large and small banks (Berger et al. 2006; Berger and DeYoung 2001; Brickley et al. 2003; Deng and Elyasiani

\footnotetext{
${ }^{13}$ We calculate the level of regional protectionism in each target market and then the regional protectionism index of the target market as a whole. Finally, we divide the number of target markets. The average of local protectionism in target markets is the regional protectionism index.
} 
Table 8 Local protectionism

\begin{tabular}{|c|c|c|c|c|c|}
\hline Dependent variable & (1) $R O A$ & (2) $R O E$ & (3) NPL ratio & (4) Cost & (5) Market share \\
\hline $\operatorname{Protect} \times(1-H H)$ & $-0.097^{c}(0.025)$ & $-1.510^{c}(0.401)$ & $12.453^{\mathrm{a}}(6.603)$ & $0.113^{c}(0.031)$ & $-0.065(0.644)$ \\
\hline Protect & $0.013(0.011)$ & $0.242(0.177)$ & $-2.859(2.911)$ & $0.002(0.014)$ & $-0.649^{\mathrm{b}}(0.284)$ \\
\hline $1-H H I$ & $-0.010^{c}(0.002)$ & $-0.165^{c}(0.030)$ & $2.751^{c}(0.495)$ & $0.013^{c}(0.002)$ & $0.362^{c}(0.048)$ \\
\hline Loan ratio & $0.004(0.003)$ & $-0.047(0.045)$ & $0.523(0.749)$ & $0.025^{c}(0.004)$ & $0.406^{\mathrm{c}}(0.073)$ \\
\hline Asset ratio & $-0.001^{c}(0.004)$ & $-0.024^{c}(0.007)$ & $-0.173(0.120)$ & $-0.001(0.001)$ & $-0.010(0.012)$ \\
\hline Capital & $0.003(0.017)$ & $-0.447^{\mathrm{C}}(0.067)$ & $-1.198(1.118)$ & $0.010^{\mathrm{a}}(0.005)$ & $-0.248^{b}(0.109)$ \\
\hline Asset quality & $0.003(0.002)$ & $-0.016(0.029)$ & $0.132(0.479)$ & $0.000(0.002)$ & $0.012(0.047)$ \\
\hline GDP & $0.018(0.027)$ & $0.083^{\mathrm{a}}(0.045)$ & $-0.025^{\mathrm{C}}(0.007)$ & $-0.027(0.034)$ & $-0.064^{\mathrm{C}}(0.007)$ \\
\hline Age & $-0.002(0.002)$ & $-0.010^{c}(0.003)$ & $-0.320^{c}(0.048)$ & $-0.003^{c}(0.007)$ & $-0.028^{c}(0.005)$ \\
\hline Size & $0.007^{b}(0.003)$ & $0.001^{\mathrm{a}}(0.001)$ & $0.011(0.010)$ & $0.001(0.004)$ & $0.012^{c}(0.001)$ \\
\hline Constant & $0.011^{\complement}(0.003)$ & $0.322^{c}(0.051)$ & $6.404^{c}(0.822)$ & $0.048^{\mathrm{C}}(0.004)$ & $0.860^{\complement}(0.080)$ \\
\hline Year fixed effects & Yes & Yes & Yes & Yes & Yes \\
\hline Bank fixed effects & Yes & Yes & Yes & Yes & Yes \\
\hline N & 736 & 736 & 741 & 729 & 741 \\
\hline$R^{2}$ & 0.504 & 0.505 & 0.450 & 0.621 & 0.973 \\
\hline
\end{tabular}

Notes. Standard errors are robust and reported in parentheses. ${ }^{\mathrm{a}}, \mathrm{b}$, and ${ }^{\mathrm{c}}$ indicate significance at $10 \%, 5 \%$, $1 \%$ levels, respectively

2008; Goetz et al. 2013; Wang et al. 2012). Banks with a capital of USD25 million to USD500 million could experience improved performance due to the expansion. Berger et al. (1995), Marcus (1983), and Rime and Stiroh (2003) suggest that the capital adequacy ratio has a positive and significant relationship with ROA. Bank characteristics will influence bank performance. We conduct several cross-sectional analyses and classify the sample into two subsamples based on bank characteristics.

We select bank characteristics, including size, age, capital adequacy, NPLs, and non-interest income. We separate our sample into two subsamples by the median of each bank characteristic. The observations greater than the median are classified as the higher subsample; other observations are classified as the lower subsample. We run the estimation of Eq. (3) for each subsample and present the results in Table 9.

Panel A of Table 9 indicates that the size of banks has no significant effect on the impact of geographical diversification on bank performance. Panel B of Table 9 shows that geographic expansion by younger banks contributes additionally to worse performance, while the impact on performance in larger city commercial banks becomes insignificant. Panel $\mathrm{C}$ of Table 9 indicates that geographic expansion by a bank with a lower capital adequacy ratio contributes to worse performance, while the impact on the performance of a bank with a higher capital adequacy ratio is insignificant. Panel D of Table 9 suggests that geographic expansion by higher NPLs contributes to worse bank performance, while the impact on the performance of banks with lower NPLs is insignificant. Panel E of Table 9 suggests that geographic expansion by higher non-interest income contributes to worse returns, while the impact on lower non-interest income contributes to operating costs. The results for market share are positive and significant for both subsamples. 


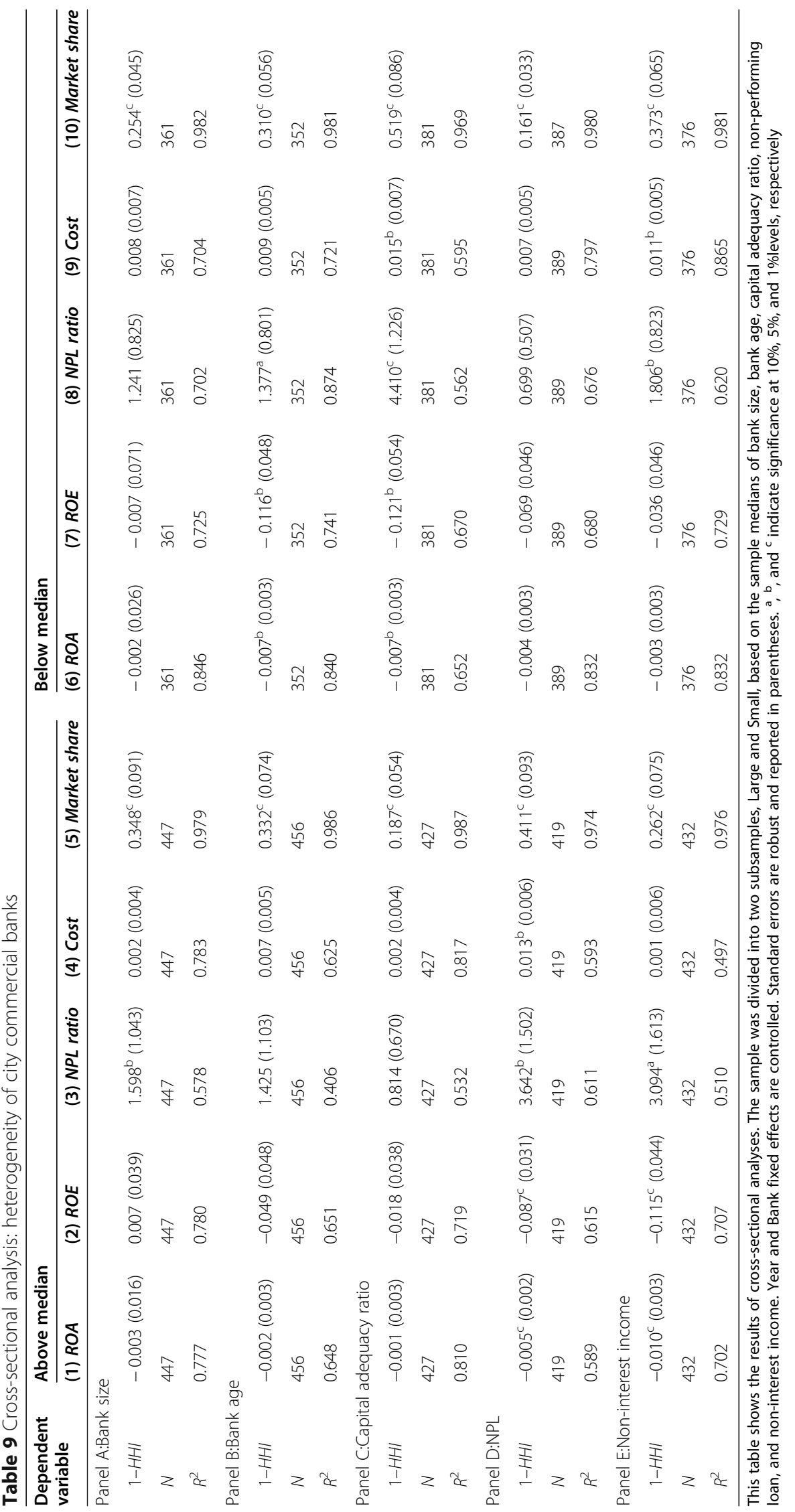




\section{Conclusion}

We extend our work by examining the impact of geographic diversification changes that resulted from deregulation on bank performance. Our baseline results suggest that geographic diversification of banks decreases their performance but increases their market share. Moreover, the result of the 2SLS regression using the instrument calculated from the gravity model is consistent with the baseline result. We also add a different explanation in this study. While some existing studies argue that geographic expansion leads to better performance due to cost reduction and scale effects, other studies highlight that geographic expansion increases the distance between headquarters and branches, leading to complexity in monitoring activities and risk management and decreasing bank performance. We find that the external environment and market structure in the target market reduce city commercial banks' performance. More specifically, different from the existing research, we perform some mechanism tests based on the Chinese market context. First, our findings are driven by the level of local protectionism in the target market and the number of large- and medium-sized banks. Higher levels of local protectionism and a higher number of large- and mediumsized banks dominate the target market and worsen the performance after deregulation. Second, compared with state-owned city commercial banks, non-stateowned city commercial banks are more likely to perform worse. According to our empirical results, in addition to the reasons for the scale effect and internal controls, the external environment, market structure, and ownership structure of banks also impact bank performance after geographic expansion.

The main differences between this study and other existing research are the following: (1) Our sample is different from those in other studies. Wang et al. (2012) use financial data on 104 city commercial banks from 2004 to 2009. They focus on the policy implemented in 2006. At this stage, only eligible city commercial banks were permitted to expand. Therefore, the sample might have a selection bias. However, our research includes the two phases of Chinese deregulation. Li (2014) uses bank financial data from 2008 to 2012, including 106 city commercial banks, 69 rural commercial banks, and 39 rural cooperative banks. However, rural commercial banks and rural cooperative banks have not been allowed to operate cross-regionally. Cai (2016) uses a sample of joint-equity commercial banks and city commercial banks. However, joint-equity commercial banks are not limited across regions, as they hold a nationwide license. This paper addresses these challenges. (2) Wang et al. (2012) and Li (2014) use the Heckman selection model (without IV) to overcome sample selection bias. Cai (2016) uses the interaction term between policy and the initial capital adequacy ratio of the bank. We use a policy shock and gravity model to construct an instrumental variable to overcome endogenous unobservable variables. This method is relatively exogenous. (3) The research mechanisms are different. Wang et al. (2012) and Li (2014) use the mechanism of the distance between the "home" city and other cities. However, following the geographic expansion of city commercial banks, the worse performance is due to market circumstances in China. Therefore, we pay more attention to market structure, local protectionism, and the ownership of city commercial banks. 
Our results also have practical significance. First, the supervision department should build prudent regulations permiting well-performing city commercial banks to establish cross-regional branches. Meanwhile, city commercial banks should focus on local businesses, avoiding blind expansion to achieve a larger market share. Second, the government should pay more attention to local protectionism, as it leads to market segmentation and harms resource allocation. Third, city commercial banks should consider the market structure and administrative factors of the target market. Sufficient market surveys and accurate market positioning in the new market are necessary for a bank's cross-regional development. Finally, a good way to thrive in the target market is to implement different competitive strategies and elude conflict with state-owned banks and joint-equity banks. Thus, city commercial banks should pay particular attention to their local markets and concentrate on serving the local economy.

\section{Appendix}

Table 10 List of variables

\begin{tabular}{|c|c|c|}
\hline Variable & Definition & Source \\
\hline $1-H H I$ & $\begin{array}{l}\text { Branches dispersion index as a measure of geographic diversification, } 1-\text { Herfindahl } \\
\text { index of branches across cities is one minus the sum of squared branches held in } \\
\text { other cities }\end{array}$ & CBRC \\
\hline Age & The number of years since the bank has existed & CSMAR \\
\hline Asset ratio & The growth rate of total assets & CSMAR \\
\hline Asset quality & Loan loss reserves divided by gross loans & CSMAR \\
\hline Avg distance & $\begin{array}{l}\text { The average distance between a city bank's headquarter's county and the county of } \\
\text { its affiliated subsidiary banks }\end{array}$ & CBRC \\
\hline Capital & Book value of equity capital divided by total assets & CSMAR \\
\hline Cost & The ratio of operating cost, measured by (Operating cost)/ (Total Cost) & CSMAR \\
\hline Distance & the distance between bank's "home" city and other cities & CBRC \\
\hline $\begin{array}{l}\text { Diversification } \\
\text { dummy }\end{array}$ & $\begin{array}{l}\text { A dummy variable that takes on the value of one if a city bank has subsidiaries in } \\
\text { other cities and zero otherwise. }\end{array}$ & CBRC \\
\hline GDP & Gross domestic product of the bank's headquarter city & CSMAR \\
\hline Loan ratio & Total loan ratio, measured by the bank's annual loan divided by the total asset & CSMAR \\
\hline Market share & $\begin{array}{l}\text { The market share of the loan, measured by the total loan of one city commercial } \\
\text { bank divided by the total loan of the city commercial banks' sector }\end{array}$ & CSMAR \\
\hline NPL ratio & $\begin{array}{l}\text { Non-performing loan is given as (Non-performing Loan) / (Total loan), measured by } \\
\text { the sum of loans past their } 90 \text {-day due or more and still accruing, and the non- } \\
\text { accrual loans, divided by total loans }\end{array}$ & CNRDS \\
\hline$R O A$ & ROA is given as (Net income) / (Total asset) & CSMAR \\
\hline ROE & ROE is given as (Net income) / (Total equity) & CSMAR \\
\hline Size & The book value of the bank's total assets & CSMAR \\
\hline
\end{tabular}




\section{Abbreviations}

CBRC: China Banking Regulatory Commission; HHI: Herfindahl index; NPL: Non-performing loan; PBC: People's Bank of China; ROA: Return on asset; ROE: Return on equity

\section{Acknowledgements}

We received very helpful comments from anonymous referees. We also thank seminar participants at Renmin University of China for their helpful comments and discussions. All errors are ours.

\section{Authors' contributions}

$X L$ and $C S$ designed the study. $X L$ performed the research, collected and analyzed the data, and wrote the paper. The author(s) read and approved the final manuscript.

\section{Funding}

Not applicable.

\section{Availability of data and materials}

1. The bank branch data that support the findings of this study are available in: http://xukezheng.cbrc.gov.cn/ilicence/ licence/licenceQuery.jsp

2. The bank financial data that support the findings of this study are available in: http://www-cnrds-com-s.vpn.ruc.edu. $\mathrm{cn} /$ Home/Index\#/AllDatabase

3. The city information data that support the findings of this study are available in: http://www-gtarsc-com.vpn.ruc.edu. $\mathrm{cn} /$ SingleTable/DataBaselnfo?nodeid=23

4. All the details of information above that support the findings of this study are available from the corresponding author upon reasonable request, if needed. lixiaonan19901008@163.com

\section{Declarations}

\section{Competing interests}

The authors declare that they have no competing interests.

Received: 12 February 2020 Accepted: 4 April 2021

Published online: 07 July 2021

\section{References}

Akhigbe, A., \& Whyte, A. M. (2003). Changes in market assessments of bank risk following the Riegle-Neal Act of 1994. Journal of Banking \& Finance, 27(1), 87-102.

Bai, C., Du, L., Tao, Z., \& Tong, Y. (2004). Local protectism and industrial concentration in China: Overall trend and important factors. Economic Research, 4, 29-40.

Bain, J. S. (1956). Barriers to new competition: Their character and consequences in manufacturing industries. Harvard University Press.

Baum, F., Caglayan, M., \& Talavera, O. (2010). Parliamentary election cycles and the Turkish banking sector. Journal of Banking \& Finance, 34(11), 2709-2719.

Berger, A. N., Demsetz, R. S., \& Strahan, P. E. (1999). The consolidation of the financial services industry: Causes, consequences, and implications for the future. Journal of Banking \& Finance, 23(2-4), 135-194.

Berger, A. N., \& DeYoung, R. (2001). The effects of geographic expansion on bank efficiency. Journal of Financial Services Research, 19(2/3), 163-184.

Berger, A. N., Hanweck, G. A., \& Humphrey, D. B. (2006). Competitive viability in banking scale, scope, and product mix economies. Journal of Monetary Economics, 20(3), 501-520.

Berger, A. N., Herring, R. J., \& Szego, G. P. (1995). The role of capital in financial institutions. Journal of Banking \& Finance, 19(34), $393-430$.

Brickley, J. A., Linck, J. S., \& Smith Jr., C. W. (2003). Boundaries of the firm: Evidence from the banking industry. Journal of Financial Economics, 70(30), 351-383.

Cai, W. (2016). Deregulation of branching restriction, geographical diversification and bank's performance. Journal of Financial Research, 6, 127-141.

Calomiris, C. W., \& Mason, J. R. (2003). Fundamentals, panics, and bank distress during the depression. The American Economic Review, 93(5), 1615-1647.

Chandler Jr., A. D. (1977). The visible hand: The managerial revolution in American business. Harvard Belknap.

Chong, B. S. (1991). The effects of interstate banking on commercial banks' risk and profitability. The Review of Economics and Statistics, 73(1), 78-84.

Cornett, M., Guo, L., Khaksari, S., \& Tehranian, H. (2008). The impact of corporate governance on performance differences in privately-owned versus government-owned banks: An international comparison, Working paper. Boston College.

Degryse, H., \& Ongena, S. (2005). Distance, lending relationships, and competition. Journal of Finance, 60(1), 231-266.

Demirgüç-Kunt, A., \& Harry, H. (1999). Determinants of commercial bank interest margins and profitability: Some international evidence. SSRN Working Paper.

Demsetz, R. S., \& Strahan, P. E. (1973). Diversification, size, and risk at bank holding companies. Journal of Money, Credit and Banking, 29(3), 300-313.

Deng, S., \& Elyasiani, E. (2008). Geographical diversification, bank holding company value, and risk. Journal of Money, Credit and Banking, 40(6), 1217-1238.

Diamond, D. W. (1984). Financial intermediation and delegated monitoring. Review of Economic Studies, 51(3), 393-414. 
DiMaggio, P., \& Powell, W. (1983). The iron cage revisited: Institutional isomorphism and collective rationality in organizational fields. American Sociological Review, 48(2), 147-160.

Fabrizio, K. R., \& Thomas, L. G. (2012). The impact of local demand on innovation in a global industry. Strategic Management Journal, 33(1), 42-64.

Franklin, A., \& Douglas, G. (2000). Financial contagion. Journal of Political Economy, 108(1), 1-33.

Gerashchenko, A. (1962). Economic backwardness in historical perspective. Harvard University Press.

Gertner, R., Scharfstein, D., \& Stein, J. (1994). Internal versus external capital markets. Quarterly Journal of Economics, 109(4), $1211-1230$.

Goetz, M., Laeven, L., \& Levine, R. (2013). Identifying the valuation effects and agency costs of corporate diversification: Evidence from the geographical diversification of U.S. banks. Review of Financial Studies, 26(7), 1787-1823.

Goetz, M., Laeven, L., \& Levine, R. (2016). Does the geographic expansion of banks reduce risk? Journal of Financial Economics, $120(2), 346-362$.

Greenwald, B., \& Stiglitz, J. (1986). Externalities in economies with imperfect information and incomplete markets. Quarterly Journal of Economics, 101(2), 229-264.

Guo, F. (2014). Endogenous conditions and competitive effect of the establishment of local financial institutions in China: An analysis of the county banks using spatial Probit model. Quarterly Journal of Economics, 8(2), 36-56.

Guo, F., \& Xiong, R. (2018). Local financial institutions and regional economic growth: A quasi-natural experiment of city commercial banks in China. Quarterly Journal of Economics, 16(1), 221-246.

Hainz, C. \& Hakenes, H. (2007). The politician and his banker. CESifo working paper no.2153.

Houston, J., James, C., \& Marcus, D. (1997). Capital market frictions and the role of internal capital markets in banking. Journal of Financial Economics, 46(2), 135-164.

Hu, J., \& Guo, F. (2013). Rent-seeking, bureaucratic corruption and market segmentation. Economic Management, 11, 36-47.

$\mathrm{Hu}, \mathrm{X}$., \& Zhang, L. (2005). Local protectionism and regional specialization: A model and econometric evidences. Economic Research Journal, 2, 102-112.

Huang, Z., \& Wang, J. (2006). Local protectionism and market fragmentation: An experience study in China. Chinese Industrial Economy, 2, 60-67.

Hughes, J. P., Lang, W., Mester, L. J., \& Moon, C. (1996). Efficient banking under interstate branching. Journal of Money, Credit and Banking, 13(4), 1045-1071.

lannotta, G., Nocera, G., \& Sironi, A. (2007). Ownership structure, risk and performance in the European banking industry. Journal of Banking \& Finance, 31(7), 2127-2149.

Jiang, H., Jiang, P., \& Zou, P. (2008). Oligopoly, risk-based competition and developmental dilemma of small and medium banks in China: 2001-2006. Contemporary Finance \& Economics, 12, 59-65.

Körner, T., \& Schnabel, I. (2011). Public ownership of banks and economic growth: The impact of country heterogeneity. The Economics of Transition, 19(3), 407-441.

Kuppuswamy, V., \& Villalonga, B. (2016). Does diversification create value in the presence of external financing constraints? Evidence from the 2007-2009 financial crisis. Management Science, 62(1), 905-1224.

Levy-Yeyati, E., Martinez, P., \& Schmukler, S. (2004). Market discipline in emerging economies: Beyond bank fundamentals. In C. Borio, W. Hunter, G. Kaufman, \& K. Tsatsaronis (Eds.), Market discipline across countries and industries. MIT Press.

Lewis, A. (1950). The principles of economic planning. Allen and Vnwin Press.

Li, G. (2014). Cross-regional operation and performance of small and medium-sized banks. The Journal of World Economy, 11, $119-145$.

Lin, Y., \& Liu, P. (2004). Regional protectionism and market segmentation: From the perspective of developments strategy, Working paper no. C2004015. China Center for Economic Research, Peking University.

Liu, W., \& Huang, G. (2002). Challenges for China's banks reform: Ownership structure or market structure. Economic Research Journal, 8, 3-11.

Marcus, A. J. (1983). The bank capital decision: Time series—Cross section analysis. Journal of Finance, 38(4), 1217-1232.

Meslier, C., Morgan, D. P., Samolyk, K., \& Tarazi, A. (2016). The benefits and costs of geographic diversification in banking. Journal of International Money \& Finance, 69, 287-317.

Meyer, J. W., \& Rowan, B. (1977). Institutionalized organizations: Formal structure as myth and ceremony. American Journal of Sociology, 83(2), 340-363.

Mian, A. (2003). Foreign, private domestic, and government banks: New evidence from emerging markets. Mimeo, University of Chicago.

Micco, A., Panizza, U., \& Yanez, M. (2007). Bank ownership and performance. Does politics matter? Journal of Banking \& Finance, 31(1), 219-241.

Poncet, S. (2003). Measuring Chinese domestic and international integration. China Economic Review, 14(1), 1-21.

Poncet, S. (2010). A fragmented China: Measure and determinants of Chinese domestic market disintegration. Review of International Economics, 13(3), 409-430.

Porta, R. L. (2012). Expectations and the cross-section of stock returns. Journal of Finance, 51(5), 1715-1742.

Rime, B., \& Stiroh, K. J. (2003). The performance of universal banks: Evidence from Switzerland. Journal of Banking and Finance, $27(11), 2121-2215$.

Schotter, A. P., Mudambi, R., Doz, Y. L., \& Gaur, A. (2017). Boundary spanning in global organizations. Journal of Management Studies, 54(4), 403-421.

Shen, C., \& Lin, C. (2012). Why government banks underperform: A political interference view. Journal of Financial Intermediation, 21(2), 181-202.

Stiglitz, E. (1993). The role of the state in financial markets. In Proceedings of the World Bank annual conference on economic development. International Bank for Reconstruction and Development/World Bank.

Stiglitz, E., \& Weiss, A. (1981). Credit rationing in markets with imperfect information. American Economic Review, 71, 393-410.

Tian, X. (2012). The role of venture capital syndication in value creation for entrepreneurial firms. Review of Finance, 16(1), 245-283.

Wang, Q., Wu, W., \& Huang, J. (2012). Cross-regional operation of city commercial banks: Credit expansion, risk level and bank performance. The Journal of Financial Research, 1, 141-153. 
Wernerfelt, B. (1995). A resource-based view of the firm. Strategic Management Journal, 16(3), 171-174.

Wong, C. (2003). Economic growth under decentralization: Old wine in new bottles? Another look at fiscal incentives in

China. In Paper presented at the work-shop on national integration. Organized by the World Bank and China's

Development Research Center, State Council.

World Bank (2001). Finance for growth: Policy choices in a volatile world. Oxford University Press.

Xu, C. (2011). The fundamental institutions of China's reform and development. Journal of Economic Literature, 49(4), 10761151.

Young, A. (2000). The razor's edge: Distortions and incremental reform in the People's Republic of China. Quarterly Journal of Economics, 115(4), 1091-1135.

Zhang, H. (2006). Oligopoly market structure and the development of Chinese banking industry. Statistics and Decision, 12, 106-107.

Zhang, J., Zheng, W., \& Xin, F. (2017). Bank deregulation, structural competition and enterprises, innovation in China. China Industrial Economics, 10, 118-136.

Zhao, X., \& Zhang, L. (1999). Decentralization reforms and regionalism in China: A review. International Regional Science Review, 22(3), 251-281.

Zhou, L. (2004a). The incentive and cooperation of government officials in the political tournaments: An interpretation of the prolonged local protectionism and duplicative investments in China. Economic Research Journal, 6, 33-40.

Zhou, L. (2004b). Governing China's local officials: An analysis of promotion tournament model. Economic Research Journal, 7 , $36-50$

Zhou, L. (2007). Governing China's local officials: An analysis of promotion tournament model. Economic Research Journal, 7, $36-50$.

\section{Publisher's Note}

Springer Nature remains neutral with regard to jurisdictional claims in published maps and institutional affiliations.

\section{Submit your manuscript to a SpringerOpen ${ }^{\circ}$ journal and benefit from:}

- Convenient online submission

- Rigorous peer review

- Open access: articles freely available online

High visibility within the field

- Retaining the copyright to your article

Submit your next manuscript at $\boldsymbol{\nabla}$ springeropen.com 